\title{
PROPRIORECEPCIJOS IR LIEMENS STABILUMO PRATIMŲ POVEIKIS JAUNŲJŲ FUTBOLININKŲ PUSIAUSVYRAI
}

\author{
Gvidas Kaziūnas, Brigita Zachovajevienè \\ Kauno kolegija
}

\section{SANTRAUKA}

Tyrimo pagrindimas. Futbolas yra viena iš populiariausių sporto šakų visame pasaulyje (Ricotti et al., 2013). Daugiau kaip pusė futbolą žaidžiančių asmenų yra jaunesni nei aštuoniolikos metų (Rössler et al., 2018). Lyginant riziką patirti čiurnos traumą tarp skirtingų amžiaus grupių, vaikai ir paaugliai turi didesnę tikimybę patirti traumą negu suaugę (Doherty et al., 2014).

Tikslas - nustatyti propriorecepcijos ir liemens stabilumo pratimų poveikį jaunųjų futbolininkų pusiausvyrai.

Metodai. Buvo tiriama 14 futbolo mokyklos „X“ komandos žaidejų. Tiriamieji buvo suskirstyti ị dvi grupes: propriorecepcijos pratimų bei propriorecepcijos ir liemens stabilumo pratimų. Tyrimo pradžioje ir pabaigoje buvo vertinta: statinè ir dinaminè pusiausvyra, liemens raumenų statinè ištvermè.

Rezultatai. Vertinant statinę pusiausvyrą nustatyta, kad abiejose grupėse statistiškai reikšmingai pakito šie rodikliai: sumažejo maksimalus nuokrypis atgal, vidutinis vaizdinio ilgis, vidutinis greitis frontalioje plokštumoje, vidutinis greitis sagitalioje plokštumoje ir vidutinis vaizdinio ilgis $(\mathrm{p}<$ $0,05)$. Pirmoje grupeje taip pat sumažejo maksimalus nuokrypis ị priekị $(p=0,001)$, antroje - vidutinis nuokrypis frontalioje plokštumoje $(\mathrm{p}=0,045)$. Vertinant dinaminę pusiausvyrą nustatyta, kad visi rodikliai statistiškai reikšmingai pagerejo abiejose grupèse $(\mathrm{p}<0,05)$.

Išvados:

1. Propriorecepcijos pratimų programa gerina jaunųjų futbolininkų statinę ir dinaminę pusiausvyrą, didina liemens raumenų statinę ištvermę.

2. Propriorecepcijos ir liemens stabilumo pratimų programa gerina jaunujų futbolininkų statinę ir dinaminę pusiausvyrą, didina liemens raumenu statinę ištvermę.

3. Propriorecepcijos lavinimas daro didesnę itaką dinaminei pusiausvyrai, propriorecepcijos ir liemens stabilumo programa labiau veikia statinę liemens raumenų ištvermę. Abi programos vienodai gerina statinę pusiausvyrą.

Raktažodžiai: propriorecepcija, liemens stabilumas, pusiausvyra, jaunieji futbolininkai.

\section{IVADAS}

Futbolas yra viena iš populiariausių sporto šakų visame pasaulyje, turinti apie 250 milijonų aktyvių žaidèjų (Ricotti et al., 2013). Ši sporto šaka yra labai populiari jaunesniojo amžiaus asmenų grupėse, nes daugiau kaip pusė futbolą žaidžiančių asmenų yra jaunesni nei aštuoniolikos metų (Rössler et al., 2018). Ir nors sportas bei fizinis aktyvumas yra susiję su ilgalaikiais teigiamais viso kūno ir jo sistemu pokyčiais, kultivuojant tokią greito tempo kontaktinę sporto šaką kaip futbolas, dažnai pasitaiko traumų. Nukenčia ne tik traumą patyręs žaidejjas (jis praranda savo sportinę formą ir svarbų žaidimo laiką aikštelejje), bet ir visa komanda negalèdama varžytis geriausia sudètimi. Dėl šių priežasčių traumų prevencija yra 
svarbi kultivuojant bet kurią sporto šaką, ir tai turi būti nuolat tiriama ir tobulinama (Gonell et al., 2015). Nagrinejjant čiurnos traumas, dažniausiai pasitaikančias žaidžiant futbolą, pastebèta, kad vaikai ir paaugliai turi didesnę tikimybę patirti čiurnos traumą negu suaugusieji (Doherty et al., 2014). Viena iš svarbiausių fizinių savybių, leidžiančių futbolininkui puikiai varžytis, yra gerai išlavinta pusiausvyra, nes žaidžiant futbolą koja dažniausiai turi atlikti vieną iš dviejų funkcijų: atraminę, stabilizavimo arba kamuolio spyrimo, perdavimo. Šie judesiai gali būti lengvai atliekami tik tada, kai gerai kontroliuojama pusiausvyra (Pau et al., 2015). Nors gerai pusiausvyrai pasiekti dažniausiai yra naudojamos propriorecepcijos gerinimo treniruotès, vis dar nèra išskiriamas geriausias ir optimaliausias būdas treniruoti pusiausvyrą. Dẻl to vis dažniau yra diskutuojama tema - koks propriorecepcijos ir liemens stabilumo pratimų poveikis jaunujų futbolininkų pusiausvyrai. Turint stiprius liemenị stabilizuojančius raumenis, geriau yra kontroliuojama statinè ir dinaminè pusiausvyra, sumažeja kojų traumų rizika (Watson et al., 2017).

Tyrimo tikslas - nustatyti propriorecepcijos ir liemens stabilumo pratimų poveikị jaunųjų futbolininkų pusiausvyrai.

Tyrimo objektas - jaunųų futbolininkų statinè ir dinaminè pusiausvyra, statinè liemens raumenų ištvermè.

\section{METODAI}

Tyrimas atliktas 2019 metų vasario-kovo mènesiais futbolo mokykloje „X“. Tyrimui atlikti gautas Kauno kolegijos Medicinos fakulteto Reabilitacijos katedros Bioetikos komiteto leidimas. Prieš atliekant tyrimą, tiriamieji buvo supažindinti su tyrimu ir jo tikslais, gauti tiriamujų bei jų tėvų / globejjų dalyvavimą patvirtinantys sutikimai. Tiriamoji imtis - futbolo mokyklos „X“ komandos žaidejjai. Tiriamuju atrankos kriterijai:

1. Amžius $12-13$ metų.

2. Sportuojantys ne trumpiau kaip 2 metus.

Buvo tiriama 14 vaikinų. Tiriamụjų amžiaus vidurkis $-12,86 \pm 0,36 \mathrm{~m}$. Atsitiktine tvarka tiriamieji buvo suskirstyti ị dvi grupes, kurios pagal amžiaus, ūgio, svorio ir kūno masès indekso (KMI) rodiklius buvo homogeniškos. Išsamesnè tiriamujų charakteristika pateikta 1 lentelèje. 
1 lentelè. Tiriamųjų charakteristika

\begin{tabular}{|l|c|c|}
\hline Rodikliai & 1 grupé & 2 grupé \\
\hline Amžius $(\mathrm{m})$. & $12,86 \pm 0,38$ & $12,86 \pm 0,38$ \\
\hline Ūgis $(\mathrm{m})$ & $1,57 \pm 0,07$ & $1,55 \pm 0,02$ \\
\hline Svoris $(\mathrm{kg})$ & $47,14 \pm 3,48$ & $43,86 \pm 2,91$ \\
\hline KMI $\left(\mathrm{kg} / \mathrm{m}^{2}\right)$ & $19,06 \pm 0,85$ & $18,25 \pm 0,97$ \\
\hline
\end{tabular}

Tiriamiesiems buvo taikoma 4 savaičių trukmès propriorecepcijos ir propriorecepcijos bei liemens stabilumo lavinimo programos. Užsièmimai vyko 2 kartus per savaitę. Kiekvienos futbolo treniruotės pradžioje, po pramankštos, abi grupès bendrai atlikdavo 10 minučių propriorecepcijos lavinimo pratimus. Buvo atliekami 5 pratimai kaire ir dešine kojomis, kiekvienas truko 45 sekundes. Pratimų atlikimo tvarka:

1. Stovèti ant vienos kojos atmerktomis akimis.

2. Sovèti ant vienos kojos, kita koja ridenti kamuolị aplink atraminę koją.

3. Laikant kamuolį rankose, stovèti ant vienos kojos, per kelį sulenktą koją pakelti ị viršų prieš save ir perduoti kamuolị iš vienos rankos ị kitą po sulenktos kojos keliu. Tada ištiesti koją atgal ir liemeniu lenktis pirmyn bei perduoti kamuolị iš vienos rankos ị kitą už atraminès kojos.

4. Stovèti ant vienos kojos, kita koja atmušti metamą kamuoli taip, kad kamuolys vèl atsidurtų komandos draugo rankose.

5. Stovèti ant vienos kojos užmerktomis akimis.

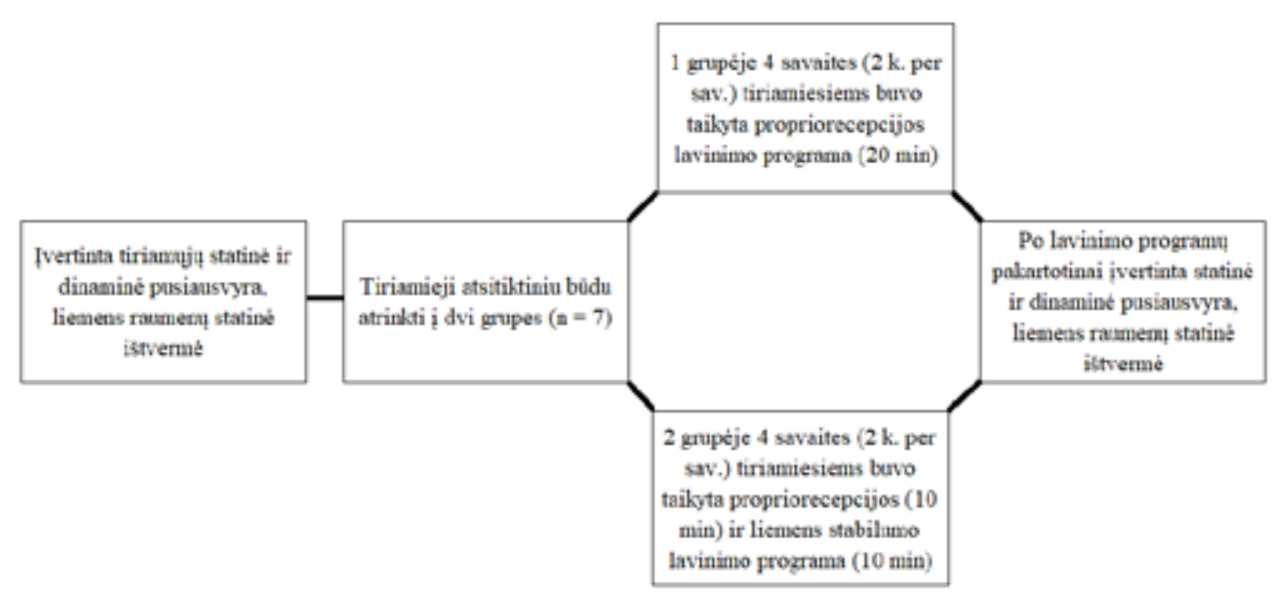

Pav. Tyrimo organizavimo schema 
Futbolo treniruotės pabaigoje pirma grupè 10 minučių atlikdavo propriorecepcijos lavinimo pratimus. Pratimai buvo tokie patys, kaip ir pirmoje dalyje, tik atliekami ant nestabilios plokštumos. Antra grupe atlikdavo 10 minučių trukmès liemens lavinimo pratimus. Visi McGill liemens raumenų statinès ištvermès testai buvo naudoti kaip liemens stabilumo lavinimo pratimai. Remiantis U. Granacher ir kt. (2014) taikyta programa, visi pratimai buvo atliekami po 30 sekundžių, vienas paskui kitą, 3 kartus, po pratimų ciklo darant 1 minutès ir 30 sekundžių pertraukas.

Tyrimo organizavimo schema pateikta 1 paveiksle.

\section{Tyrimo metodai}

Balansavimo (pusiausvyros) platforma SIGMA. Testas skirtas ịvertinti asmens statinę pusiausvyrą. Tyrimas buvo atliekamas pagal specialius tyrimo etapus: 1) prieš kiekvieną testavimą buvo atliekamas platformos sukalibravimas; 2) tiriamasis buvo informuojamas apie tyrimą ir perspejamas, kaip elgtis staiga praradus pusiausvyrą; 3) kiekvienam tiriamajam buvo leidžiama kelias minutes pastovèti ant platformos; 4) pakartotinis platformos sukalibravimas; 5) pusiausvyros testavimas kompiuteriu registruojant duomenis (30 s). Tyrimo metu tiriamasis buvo prižiūrimas, kad būtų užtikrintas jo saugumas. Taip pat buvo padedama saugiai užlipti ir nulipti nuo platformos.

Pusiausvyra buvo vertinama pagal dešimt objektyvių rodiklių: maksimalų nuokrypi ị dešinę ir ị kairę, maksimalų nuokrypi i priekị ir atgal $(\mathrm{cm})$, vidutinị nuokrypi nuo $X$ ir $Y$ ašiu $(\mathrm{cm})$, vidutinị vaizdinių judejjimo greitị $X$ ir $Y$ ašyje $(\mathrm{cm} / \mathrm{s})$, vaizdinio ilgị $(\mathrm{cm})$ ir vaizdinio plotị $\left(\mathrm{cm}^{2}\right)$ (Rutkauskienè ir kt., 2012).

\section{McGill liemens raumenų statinès ištvermès testas}

1. Pilvo raumenu statinès ištvermès testas. Tiriamojo buvo prašoma atsisèsti ant kušetės sulenkus kojas taip, kad tarp liemens ir šlaunų, šlaunų ir blauzdų būtų 90 laipsnių kampas. Rankas sukryžiuoti ant krūtinès ir delnais liesti pečius. Tiriamojo pédos buvo prilaikomos. Pradejjus testą, tokią padètį tiriamasis turèjo išlaikyti kuo ilgiau. Testas nutraukiamas, kai tiriamasis nebeišlaiko padèties arba taisyklingos padèties.

2. Nugaros raumenu statinès ištvermès testas. Tiriamasis atsigula ant kušetės veidu i grindis taip, kad nuo klubakaulių iki galvos neturètų atramos. Tiriamojo pédos prilaikomos. Tiriamasis rankas turi sukryžiuoti ant krūtinès ir delnais liesti pečius. Testas pradedamas, kai tiriamasis užima horizontalią padètị. Tokią padètị reikia išlaikyti kuo ilgiau. Testas baigiamas, kai tiriamasis nebeišlaiko viršutinès kūno dalies horizontalioje padètyje.

3. Šoniniu liemens raumenu statinès ištvermès testas. Tiriamojo buvo prašoma atsigulti šonu ant 90 laipsniu kampu per alkūnę sulenktos rankos. Viršuje esanti ranka sulenkiama per alkūnę, plaštaka uždedama ant priešingo peties. Viršu- 
je esanti koja turejo būti priekyje, o apačioje esanti - užpakalyje ištiestos kojos. Testas pradedamas, kai tiriamasis pakelia kūną nuo paviršiaus. Tokią padètị reikèjo išlaikyti kuo ilgiau. Testas baigiamas, kai tiriamasis negebėdavo išlaikyti savo kūno svorio ir nuleisdavo dubenị.

Visi testai buvo matuojami laikmačiu. Prieš kiekvieną testą tiriamasis buvo supažindinamas su testu, ir kelias sekundes buvo leidžiama išbandyti testo padèti (Kocahan, Akinoglu, 2018).

Statistinė duomenų analizė. Duomenims analizuoti buvo naudojamos ,SPSS 22 “ ir „Excel“ programos. Kintamieji tenkino pasiskirstymo normalumo sąlygą, todèl nepriklausomų imčių kintamiesiems palyginti buvo naudotas Student'o $t$ kriterijus, priklausomų imčių - porinis Student'o $t$ kriterijus.

\section{TYRIMO REZULTATAI}

Vertinant balansavimo platformos SIGMA rodiklius nustatyta, kad abiejose grupèse buvo gautas penkių rodiklių statistiškai reikšmingas teigiamas pokytis $(\mathrm{p}<0,05)$ (2 lent.). Pirmoje grupeje pagerejo šie rodikliai: maksimalus nuokrypis atgal, maksimalus nuokrypis i prieki, vidutinis greitis frontalioje plokštumoje, vidutinis greitis sagitalioje plokštumoje, vidutinis vaizdinio ilgis. Antroje grupeje statistiškai reikšmingai pagerèjo šie rodikliai: maksimalus nuokrypis atgal, vidu-

\section{2 lentelè. Pusiausvyros platformos SIGMA rodikliai}

\begin{tabular}{|l|c|c|c|c|c|c|}
\hline \multirow{2}{*}{ Rodikliai } & \multicolumn{3}{|c|}{ grupé } & \multicolumn{3}{c|}{ grupé } \\
\cline { 2 - 7 } & Prieš & Po & p & Prieš & Po & p \\
\hline $\begin{array}{l}\text { Maksimalus nuokry- } \\
\text { pis atgal (cm) }\end{array}$ & $-0,51 \pm 0,29$ & $-0,23 \pm 0,08$ & 0,005 & $-0,53 \pm 0,24$ & $-0,28 \pm 0,09$ & 0,004 \\
\hline $\begin{array}{l}\text { Maksimalus nuokry- } \\
\text { pis pirmyn (cm) }\end{array}$ & $0,28 \pm 0,12$ & $\mathbf{0 , 1 4} \pm \mathbf{0 , 0 5}$ & 0,001 & $0,35 \pm 0,18$ & $\mathbf{0 , 2 6} \pm \mathbf{0 , 1 2 *}$ & 0,179 \\
\hline $\begin{array}{l}\text { Vidutinis nuokrypis } \\
\text { frontalioje plokštu- } \\
\text { moje (cm) }\end{array}$ & $0,00 \pm 0,08$ & $0,00 \pm 0,04$ & 0,850 & $-0,04 \pm 0,08$ & $0,00 \pm 0,04$ & 0,045 \\
\hline $\begin{array}{l}\text { Vidutinis greitis fron- } \\
\text { talioje plokštumoje } \\
\text { (cm/s) }\end{array}$ & $0,30 \pm 0,06$ & $0,17 \pm 0,07$ & 0,000 & $0,39 \pm 0,16$ & $0,16 \pm 0,04$ & 0,001 \\
\hline $\begin{array}{l}\text { Vidutinis greitis sa- } \\
\text { gitalioje plokštumoje } \\
\text { (cm/s) }\end{array}$ & $0,37 \pm 0,14$ & $0,15 \pm 0,03$ & 0,000 & $0,43 \pm 0,15$ & $0,17 \pm 0,06$ & 0,000 \\
\hline $\begin{array}{l}\text { Vidutinis vaizdinio } \\
\text { ilgis (cm) }\end{array}$ & $15,75 \pm 4,32$ & $7,63 \pm 2,25$ & 0,000 & $18,19 \pm 7,01$ & $7,72 \pm 2,19$ & 0,000 \\
\hline
\end{tabular}

Pastaba. ${ }^{*}$ - reikšmingas skirtumas tarp grupių po pratimų programų taikymo $(\mathrm{p}<0,05)$. 
tinis nuokrypis frontalioje plokštumoje, vidutinis greitis frontalioje plokštumoje, vidutinis greitis sagitalioje plokštumoje, vidutinis vaizdinio ilgis.

Vertinant modifikuoto žvaigždès nuokrypio testo rodiklius nustatytas statistiškai reikšmingas teigiamas abiejų grupių visų rodiklių pokytis $(\mathrm{p}<0,05)(3$ lent.).

3 lentelè. Modifikuoto žvaigždės nuokrypio testo rodikliai

\begin{tabular}{|l|c|c|c|c|c|c|}
\hline \multirow{2}{*}{ Rodikliai } & \multicolumn{3}{|c|}{ grupé } & \multicolumn{3}{c|}{ 2 grupe் } \\
\cline { 2 - 7 } & Prieš & Po & p & Prieš & Po & p \\
\hline $\begin{array}{l}\text { Dešinès kojos judesio } \\
\text { ilgis i priekị (cm) }\end{array}$ & $60,7 \pm 5,79$ & $65,1 \pm 5,08$ & 0,000 & $67,0 \pm 5,29$ & $70,4 \pm 5,80$ & 0,000 \\
\hline $\begin{array}{l}\text { Dešinès kojos judesio } \\
\text { ilgis ị vidų (cm) }\end{array}$ & $90,9 \pm 7,06$ & $94,7 \pm 5,82$ & 0,001 & $90,9 \pm 7,49$ & $92,6 \pm 6,58$ & 0,003 \\
\hline $\begin{array}{l}\text { Dešinės kojos judesio } \\
\text { ilgis ị šoną (cm) }\end{array}$ & $92,0 \pm 7,23$ & $96,7 \pm 6,50$ & 0,001 & $93,7 \pm 8,65$ & $96,7 \pm 7,04$ & 0,005 \\
\hline $\begin{array}{l}\text { Kairès kojos judesio } \\
\text { ilgis ị priekị (cm) }\end{array}$ & $59,9 \pm 5,87$ & $62,6 \pm 4,89$ & 0,003 & $64,4 \pm 4,24$ & $66,0 \pm 4,20$ & 0,010 \\
\hline $\begin{array}{l}\text { Kairès kojos judesio } \\
\text { ilgis ị vidų (cm) }\end{array}$ & $86,0 \pm 11,46$ & $88,3 \pm 11,04$ & 0,003 & $93,7 \pm 9,32$ & $94,7 \pm 8,86$ & 0,018 \\
\hline $\begin{array}{l}\text { Kairès kojos judesio } \\
\text { ilgis į šoną (cm) }\end{array}$ & $93,9 \pm 5,70$ & $98,1 \pm 5,18$ & 0,000 & $92,3 \pm 8,26$ & $94,4 \pm 6,83$ & 0,011 \\
\hline
\end{tabular}

Vertinant McGill liemens raumenų statinès ištvermès testo rodiklius nustatytas statistiškai reikšmingas teigiamas šiu pirmos grupès rodiklių pokytis - nugaros raumenų statinè ištvermès $(p=0,000)$ ir kairès pusès liemens raumenų statinès ištvermès $(p=0,005)$. Antroje grupeje po pratimų programos buvo gautas statistiškai reikšmingas teigiamas visų rodiklių pokytis $(\mathrm{p}<0,05)$ (4 lent.).

4 lentelè. McGill liemens raumenų statinès ištvermès testo rodikliai

\begin{tabular}{|c|c|c|c|c|c|c|}
\hline \multirow{2}{*}{ Rodikliai } & \multicolumn{3}{|c|}{1 grupè } & \multicolumn{3}{|c|}{2 grupė } \\
\hline & Prieš & Po & $\mathbf{p}$ & Prieš & Po & $\mathbf{p}$ \\
\hline $\begin{array}{l}\text { Pilvo raumenų stati- } \\
\text { né išvermè (s) }\end{array}$ & $36,4 \pm 21,19$ & $37,14 \pm 16,29$ & 0,795 & $53,0 \pm 9,63$ & $75,7 \pm 11,94^{*}$ & 0,000 \\
\hline $\begin{array}{l}\text { Nugaros raumenų } \\
\text { statine ištvermé (s) }\end{array}$ & $32,4 \pm 9,27$ & $38,29 \pm 13,38$ & 0,001 & $39,9 \pm 10,24$ & $68,6 \pm 16,56^{*}$ & 0,000 \\
\hline $\begin{array}{l}\text { Dešinès pusès šoni- } \\
\text { nių liemens raumenų } \\
\text { statinè ištvermė (s) }\end{array}$ & $24,3 \pm 9,83$ & $27,86 \pm 14,68$ & 0,211 & $29,3 \pm 8,56$ & $44,7 \pm 10,06^{*}$ & 0,000 \\
\hline $\begin{array}{l}\text { Kairès pusès šoni- } \\
\text { nių liemens raumenų } \\
\text { statinė ištvermė (s) }\end{array}$ & $27,0 \pm 6,19$ & $30,57 \pm 6,24$ & 0,013 & $28,39 \pm 7,85$ & $43,1 \pm 9,55^{*}$ & 0,005 \\
\hline
\end{tabular}

Pastaba. * - reikšmingas skirtumas tarp grupių po pratimų programų taikymo $(\mathrm{p}<0,05)$. 


\section{REZULTATŲ APTARIMAS}

Vertinant statinès pusiausvyros rodiklius pirmoje grupeje, kurioje buvo atliekami tik propriorecepcijos pratimai, po 4 savaičių pratimų programos statistiškai reikšmingai pagerėjo šie rodikliai: maksimalus nuokrypis atgal, maksimalus nuokrypis ị priekį, vidutinis greitis frontalioje plokštumoje, vidutinis greitis sagitalioje plokštumoje, vidutinis vaizdinio ilgis. Statinès pusiausvyros pagerejjimas po propriorecepcijos pratimų programos buvo gautas ir M. K. Karakaya'os ir kt. (2015) tyrimo metu, kai buvo atlikta 10 propriorecepciją gerinančių treniruočių. Antroje grupeje, kurioje buvo atliekami propriorecepciją ir liemens stabilumą gerinantys pratimai, statistiškai reikšmingai pagerėjo šie rodikliai: maksimalus nuokrypis atgal, vidutinis nuokrypis frontalioje plokštumoje, vidutinis greitis frontalioje plokštumoje, vidutinis greitis sagitalioje plokštumoje, vidutinis vaizdinio ilgis. Lyginant grupes tarpusavyje, pirmoje grupeje buvo gautas statistiškai geresnis šių rodiklių pokytis - maksimalaus nuokrypio ị priekị ir vidutinio greičio frontalioje plokštumoje. Antroje grupejje gauti statistiškai geresni maksimalaus nuokrypio atgal ir vidutinio nuokrypio frontalioje plokštumoje rodiklių pokyčiai. Visi kiti reikšmingi teigiami pokyčiai buvo vienodi abiejose grupèse. Todèl vertinant statinę pusiausvyrą abiejų grupių rodiklių pokyčiai buvo panašūs.

Vertinant dinaminę pusiausvyrą pirmoje grupejje, po 4 savaičių trukmès pratimų programų statistiškai reikšmingai pagerèjo visi rodikliai. Panašus rezultatas, tačiau tik per ilgesnị laiką buvo gautas D. Tekin ir kt. (2018) tyrimu. Jie teigia, kad 8 savaičių propriorecepcijos pratimų programa statistiškai reikšmingai pagerina dinaminę pusiausvyrą. Antroje grupejje visi rodikliai taip pat pagerèjo statistiškai reikšmingai. Dinaminès pusiausvyros pagerẻjimą atliekant liemens stabilumą lavinančius pratimus taip pat pastebejo U. Granacher'is ir kt. (2014), S. F. Bashir'as ir kt. (2019). Lyginant mūsų tirtas grupes tarpusavyje, pirmoje grupeje nustatytas statistiškai geresnis šių rodiklių pokytis - kairès kojos judesio ilgis ị priekị, ị vidų ir ị šoną bei dešinès kojos judesio ilgis ị vidų ir ị šoną. Antroje grupeje pastebetas tik vienas statistiškai reikšmingas pokytis - pagerèjo dešinès kojos judesio ilgis i priekị. Todèl vertinant dinaminę pusiausvyrą galima teigti, kad pirmos grupés pratimų programa buvo efektyvesnè.

Vertinant liemens raumenų statinę ištvermę pirmoje grupejje, kurioje buvo atliekami tik propriorecepcijos pratimai, po 4 savaičių pratimų programos statistiškai reikšmingai pagerejo šie rodikliai: nugaros raumenų statinè ištvermè ir kairès pusès liemens raumenų statinè ištvermè. Antroje grupejje visi rodikliai statistiškai reikšmingai teigiamai pakito po pratimų programų. Lyginant abi grupes tarpusavyje, visi antros grupės rodikliai buvo statistiškai geresni, išskyrus nugaros raumenų 
statinès ištvermès. Todèl vertinant liemens raumenų statinę ištvermę galima teigti, kad antros grupès pratimų programa buvo efektyvesnè.

\section{IŠVADOS}

1. Propriorecepcijos pratimų programa gerina jaunujų futbolininkų statinę ir dinaminę pusiausvyrą, didina liemens raumenų statinę ištvermę.

2. Propriorecepcijos ir liemens stabilumo pratimų programa gerina jaunųjų futbolininkų statinę ir dinaminę pusiausvyrą, didina liemens raumenų statinę ištvermę.

3. Propriorecepcijos lavinimas labiau veikia dinaminę pusiausvyrą, propriorecepcijos ir liemens stabilumo programa - statinę liemens raumenų ištvermę. Abi programos vienodai gerina statinę pusiausvyrą.

\section{LITERATŪRA}

Bashir, S. F., Nuhmani, S., Dhall, R., Muaidi, Q. I. (2019). Effect of core training on dynamic balance and agility among Indian junior tennis players. Journal of Back and Musculoskeletal Rehabilitation, (Preprint), 1-8.

Doherty, C., Delahunt, E., Caulfield, B. (2014). The incidence and prevalence of ankle sprain injury: A systematic review and meta-analysis of prospective epidemiological studies. Sports Medicine [interaktyvus], 44, 123-140.

Gonell, A. C., Romero, J. A., Soler, L. M. (2015). Relationship between the y balance test scores and soft tissue injury incidence in a soccer team. International Journal of Sports Physical Therapy [interaktyvus], 10 (7), 955-966.

Granacher, U., Schellbach, J., Klein, K., Prieske, O., Baeyens, J. P., Muehlbauer, T. (2014). Effects of core strength training using stable versus unstable surfaces on physical fitness in adolescents: A randomized controlled trial. BMC Sports Science, Medicine \& Rehabilitation [interaktyvus], 6 (1), 40.

Karakaya, M. G., Rutb, H., Akpinar, E., Yildirim, A., Karakaya, I. C. (2015). Effect of ankle proprioceptive training on static body balance. Journal of Physical Therapy [interaktyvus], 27 (10), 3299-3302.

Kocahan, T., Akinoglu, B. (2018). Determination of the relationship between core endurance and isokinetic muscle strength of elite athletes. JER Journal of Exercise Rehabilitation [interaktyvus], 14 (3), 413-418.

Pau, M., Arippa, F., Leban, B. et al. (2015). Relationship between static and dynamic balance abilities in Italian professional and youth league soccer players. Physical Therapy in Sport: Official Journal of the Association of Chartered Physiotherapist in Sports Medicine [interaktyvus], 16, 236-241.

Ricotti, L., Rigosa, J., Niosi, A., Menciassi, A. (2013). Analysis of balance, rapidity, force and reaction times of soccer players at different levels of competition. PloS One [interaktyvus], 8 (10), e 77264.

Rössler, R., Junge, A., Bizzini, M. et al. (2017). A multinational cluster randomised controlled trial to assess the efficacy of '11+ Kids': A warm-up programme to prevent injuries in children's football. Sports Medicine [interaktyvus], 48 (6), 1493-1504.

Rutkauskienė, L., Piščalkienė, V., Gintilienė, M., Zachovajevienė, B., Kavaliauskienè, A. (2012). Vyresnio amžiaus asmenų pusiausvyros vertinimas naudojant „SIGMA BALANCE PAD“. Visuomenès Sveikata [interaktyvus], 22, 52-56.

Tekin, D., Agopyan, A., Baltaci, G. (2018). Balance training in modern dancers: Proprioceptive-neuromuscular training vs kinesio taping. Medical Problems of Performing Artist [interaktyvus], 33, 156-165.

Watson, T., Graning, J., McPherson, S. et al. (2017). Dance, balance and core muscle performance measures are improved following a 9-week core stabilization training program among competitive collegiate dancers. International Journal of Sports Physical Therapy [interaktyvus], 12 (1), 25-41. 


\title{
THE EFFECT OF PROPRIOCEPTION AND CORE STABILITY EXERCISES ON THE BALANCE OF YOUNG FOOTBALL PLAYERS
}

\author{
Gvidas Kaziūnas, Brigita Zachovajevienė \\ University of Applied Sciences / Kauno kolegija
}

\begin{abstract}
Background. Football is one of the most popular sports in the world (Ricotti et al., 2013). This sport is very popular among younger age groups, as more than half of those playing football are under the age of eighteen (Rössler et al., 2018). When examining ankle injuries, it has been observed that children and adolescents are more likely to experience ankle injury than adults when comparing the risk of injury between different age groups (Doherty et al., 2014).

Purpose. To determine the effect of proprioception and core stability exercises on the balance of young football players.

Methods. Fourteen football school X team players participated in the study. The subjects were divided into two groups: the first group performed proprioceptive exercises, the second performed proprioceptive and core stability exercises. The subjects were evaluated twice before and after the exercise programs with balance platform SIGMA, modified star excursion balance test, McGill core endurance tests.
\end{abstract}

Results. Evaluating the results of the SIGMA balance platform, both groups showed statistically significant positive change: maximum backward deviation, mean velocity in the frontal plane, mean velocity in the sagittal plane, mean image length $(\mathrm{p}<0.05)$. The first group also improved maximum forward deviation ( $p=$ 0.001 ), while the second group improved mean deviation in the frontal plane ( $p=$ 0.045). Results of the modified star excursion balance test showed that both groups achieved a statistically significant positive change in all test indicators.

Conclusions:

1. The proprioceptive exercise program improves the static and dynamic balance of young football players and increases the static endurance of the core muscles.

2. The proprioceptive and core stability exercise program improves the static and dynamic balance of the young football players and increases the static endurance of the core muscles.

3. The proprioceptive exercises has a greater influence on dynamic balance, proprioceptive and core stability exercise program have a greater impact on 
Propriorecepcijos ir liemens stabilumo pratimų poveikis jaunųjų futbolininkų pusiausvyrai

the static endurance of the core muscles. Both programs equally improve static balance.

Keywords: proprioception, core stability, balance, young football players.

Gautas 20190915

Priimtas 20191101 